2011-01-07

\title{
High Power, Low Frequency Ultrasound: Meniscal Tissue Interaction and Ablation Characteristics
}

\author{
Brendan O'Daly \\ Department of Trauma and Orthopaedic Surgery, Royal College of Surgeons in Ireland, Cappagh National \\ Orthopaedic Hospital, Dublin, Ireland \\ Edmund Morris \\ Dublin City University \\ Graham Gavin \\ Technological University Dublin, graham.gavin@tudublin.ie
}

See next page for additional authors

Follow this and additional works at: https://arrow.tudublin.ie/engschmanart

Part of the Biomedical Devices and Instrumentation Commons

\section{Recommended Citation}

O'Daly, B., Morris, E., Gavin, G., O'Keane, C., O'Byrne, J. and G. McGuinness (2011). High Power, Low Frequency Ultrasound: Meniscal Tissue Interaction and Ablation Characteristics. Ultrasound in Medicine \& Biology Volume 37, Issue 4, April 2011, Pages 556-567. doi:10.1016/j.ultrasmedbio.2011.01.013

This Article is brought to you for free and open access by the School of Manufacturing and Design Engineering at ARROW@TU Dublin. It has been accepted for inclusion in Articles by an authorized administrator of ARROW@TU

Dublin. For more information, please contact

arrow.admin@tudublin.ie, aisling.coyne@tudublin.ie, gerard.connolly@tudublin.ie.

Funder: Enterprise Ireland

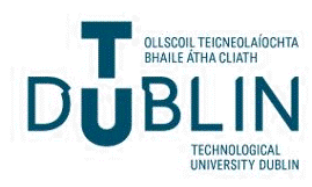


Authors

Brendan O'Daly, Edmund Morris, Graham Gavin, Conor Keane, John O Byrne, and Garrett McGuinness

This article is available at ARROW@TU Dublin: https://arrow.tudublin.ie/engschmanart/12 


\title{
HIGH POWER, LOW FREQUENCY ULTRASOUND: MENISCAL. TISSUE
}

\author{
INTERACTION AND ABLATION CHARACTERISTICS
}

\author{
BRENDAN J. O'DALY, EDMUND MORRIS, GRAHAM P. GAVIN, CONOR O'KEANE, JOHN M. O'BYRNE, \\ and GARRETT B. MCGUINNESS
}

\begin{abstract}
This study evaluates high power low frequency ultrasound transmitted via a flat vibrating prohe tip as an alternative technology for meniscal debridement in the bovine knee. An experimental force controlled testing rig was constructed using a $20 \mathrm{kHz}$ ulfrasonic probe suspended vertically from a load cell. Effect of variation in amplitude of distal tip displacement $(242-494 \mu \mathrm{m}$ peak-peak) settings and force $(2.5-4.5 \mathrm{~N})$ on tissue removal rate (TRR) and penetration rate (PR) for $\mathbf{5 2}$ bovine meniscus samples was analyzed. Temperature elevation in residual meniscus was measured by embedded thermocouples and histologic analysis. As amplitude or force increases, there is a linear increase in TRR (Mean: 0.9 to $11.2 \mathrm{mg} / \mathrm{s}$ ) and PR (Mean: 0.08 to $0.73 \mathrm{~mm} / \mathrm{s}$ ). Maximum mean temperatures of $84.6^{\circ} \mathrm{C}$ and $52.3^{\circ} \mathrm{C}$ were recorded in residual tisse at $2 \mathrm{~mm}$ and $4 \mathrm{~mm}$ from the ultrasound probe-tissue interface. There is an inverse relationship between both amplitude and force, and temperature elevafion, with higher settings resulting in less thermal damage. (E-mail garrettmcguinness@ dcuite)
\end{abstract}

\section{WTRODUCTION}

Powered cutting tools are increasingly used in orhopaedic surgery, in particular in joint arthroscopy Instruments used for the debridement of degenerative or post-traumatic cartilage and meniscal tears include hand tools, rotary shavers, lasers and radiofrequency ablation probes. The aim of meniscal debridement is to preserve critical knee function in articular congruency. cartilage protection, motion and load distribution, is well as to relieve pain. Operating time, temperature elevation and thermal damage in adjacent tissue have been cited as drawbacks to existing meniscal debridement technologies (Sherk et al. 2002). The effects of morphologic changes on meniscal tissue, knee biomechanics and joint reaction force have not been evaluated. The use of high-power low frequency ultrasound ablation instru- ments operating in the $20-60 \mathrm{kHz}$ frequency range tor this application is appealing since high power low frequency ultrasound probes are known to fragment both bone and, in combination with stction, soft tissues (Wells 1984; Cimino and bond 1996), Utrasonic instruments have not been evaluated either for meniscal debridement, or more generally, for the debridement of hard fibrots tissues. This is despite their continued use as a treament manstay for numerous other biologic tissue cutting. fragmentation and removal applications (ODaly et al. 2008). Potential clinical benefits of this strategy include efficiency, reduced operating time, and reduced temperature generation and themal damage.

Meniscal tissue is composed of water, proteoglycan and collagen ( $98 \%$ type 1 collagen), with the collagen fbres arranged in radial, circumferential and axial direcfions (Fithian et al, 1990). The meniscus behaves in load defomation as fibre-reinforced porous-permeable composite material, with creep and stress-relaxation behaviour determined by frictional drag caused by flud flow. The meniscus behaves anisotropically under unconfined compression as a consequence of collagen fibre 
orientation in the matrix (Gabrion et al 2005). Uttrasonic devices are frequently clained to exhibit the property of "tissue selectivity" which allows then to safely destroy hard tissues, while leaving nearby of tisstes unharmed The unquantified risk of thermal necrosis in adjacen cartilage and bone, as well as neurologic or vascular damage remains a concen for orthopaedic surgeons and underpins their reticence to use this technology, The objective of the current study is, therefore, to estab lish the fundamental potential of high power, low frequency ultrasound technology for debridement of fibrous meniscal and cartilaginous tissues. This study will examine the effect of contact between a tlat-tipped probe, vibrating at low ultrasonic frequencies $20-60$ $\mathrm{kHz}$ range), and meniscal tissue samples, separate from any potential effects that could arise from complex tip geometries, or sharp or serrated edges. The intention is to isolate effects due to contact with a surface vibrating at these frequencies from any other modes of cutting or tissue dissection, which might be associated with specific device designs. Experimental evidence of the tissue removal rate, probe penetration rate, temperature effects and histologic damage for a probe relying entirely on ultrasonic vibrations to ablate tissue will establish the intrinsic capability of the technology for debridement of fibrous tissues.

Literature reporting investigations of high-power ultrasonic surgical ablation and tissue failure mode in the frequency range of $20-60 \mathrm{kHz}$ is limited for all tissue types (Wells 1984, Amso 1994). Mechanical aspects of

the tissue ablation and damage mechanism are poorly understood and strategies for residual tissue damage minimisation have not been adequately addressed. Where mechanisms of interaction are reported, the available evidence is limited and frequently conflicting, The interaction between ultrasound and living lissue is complex. It depends on the type, condition and composition of tissue, mode of ultrasound application and several acoustic parameters, including frequency, amplitude of vibration, tip area, tip geometry and the resulting pressures or intensities (Cimino and Bond 1996. O'Daly et al. 2008). Few studies have quantified the relative importance of amplitude of vibration, frequency, tip design, suction or target tissue to ultrasonic device performance (Stumpht et al 1975. Duante 1983; Chan et al. 1986, Krattiger et al, 1990, Cimino and Bond 1996. Wiksell et al. 2000 ) and none relate to fobrous meniscal or cartiagnous tissue. Frequency and amplitude of tip displacement are critical factors in the ultrasound tissue interaction and their relative contribution determines the efficiency of tissue fragmentation and degree of residual tissue damage.

Quantification of ultrasonic device efficiency for soft tissue fragmentation, as well as parameters affecting cuting and removul rate, have been exanined in experimental studies, Chan et al (1986) described tissue removal using a $20 \mathrm{kHz}$ ultrasound aspirator in torms of rate per unit time using ox-inssue liver as the test material. Their method permitted examination of the effect on the rate of removal of independently varying frequency, amplitude of vibration and suction pressure. Using a similar quantitative method, Cimino and Bond (1996) identified distal tip peak-to-peak displacement and suction as the two most significant operating parameters affecting rate of fragmentation of visceral tissues. More recently, experimental investigation has focused on quantifying the effect of dissipated ultrasonic energy and resultant damage in residual tissue for individual tissue types. Recent clinical studies have highlighted the deleterious thermal and mechanical effect of ultrasonic energy in residual tissue (Emam and Cuschier 2003 ; Koch et al. 2003). Although equivalent experiments have not been performed for harder fibrous tissues, Vangness et al. (2003) have investigated the thermal damage effects of radio-frequency on the human meniscus in a force controlled experimental model. They measured a mean depth of thermal damage in residual tissue of under $2 \mathrm{~mm}$ for three commercially available devices operating in the radiofrequency range.

Three modes of interaction are recognised for ultrasound soft tissue interaction. These are (1) direct contact ablation, (2) acoustic effects in the tissues or fuids, including acoustic streaming and cavitation; (3) and thermal effects NCRP 1983. Cimino and Bond 1996;

ODaly ot al, 2008). Combined, they result in shear, fracture and material removal at the tissue surface. Solt tissue removal and damage occurs when a vibrating metal probe is brought into contact with tissue. Energy is concentrated at a narrow tip, resulting in acoustic power densities at the probe-tissue interface that are much higher than that of diagnostic and physical therapy tltrasound devices, with values ranging from 25 to 850 W/cm ${ }^{2}$ (Cimino 1999). Ablation and fragmentation effects ate seen in tissues in direct contact with the ultrasonic probe and in adjacent tisste over a range believed to be in the order of $0.01-0.1 \mathrm{~cm}$ (Cames and Dunn 1986). The treatment goal is destruction or alteration of tissues in close proximity to the probe tissue interface rather than propagation of vibratory energy in the tissues.

For hard fibrous tissues, interaction and debridement characteristics are not known. No evaluation of the acoustic energy delivered or the node of interaction has been reported. In contrast to visceral tissue, the efficiency of utrasonic ablation devices has not been quantified. Little is known about the relative contribution of acoustic parameters to efficacy and damage mechanisms. There is a paucity of studies quantifying microscopic damage in residual tissue $(0$ Daly et al, 2008). Neither has the range 
or area over which clinically relevant deleterious effects occur in these systems been subjected to rigorous investgution.

This study will investigate whether high power low frequency ultrasound transmitted via a flat ribrating probe tip can debride and danage hard fibrous nemiseal tissue to a degree that would meaningfully assist joint arthroscopy without causing unacoeptable levels of damage in residual adjacent tissue.

Ains:

The purpose of this study is to explore the resistance of bovine knee meniscus, a fibrous lissue, to ablation by contact with blunt high power, low frequency ultrasound probes. The spectic objective of this study, therefore, is to quantitatively investigate the interaction between a high power, low frequency ultrasonic probe and hard, fibrous bovine meniseal tissue, in terms of the influence of vibration amplitude and applied force on tissue removal rate, penetration rate, temperature generation and tissue damage. This study is conducted as a quantitative analysis of the parameters that contribute to this interaction.
450D, Branson Ultrasonics Corporation, Danbury, CT, USA). A $3 \mathrm{~mm}$ ultrasonte probe was connected to the actustic hon (Bratson Tapered Microtip 3 min Branson Ultrasonies Corporation). The ultrasound probe operated at $20 \mathrm{kHz}$ in continuous (nonpulsatile) mode Amplitude settings quoted correspond to manufacturer"s calibration and are based on total peak-to-peak movement in microns measured on minimum and maximum amplitude setings of the outpu control Amplitudes $(p-p)$ of 242 $\mu \mathrm{m}, 368 \mu \mathrm{m}$ and $494 \mu \mathrm{m}$ correspond to calculated spatial-average-temporal-average intensity values of 312,720 and $1298 \mathrm{~W} / \mathrm{cm}^{2}$, respectively $(\mathrm{Wu}$ and Nyborg 2006$)$.

\section{Forceldisplatement measurement system}

The acoustic hom was suspended vertically from a $500 \mathrm{~N}$ load cell $(500 \mathrm{~N}$ KAP-TC, Angewandte System Technik [AST], Dresden, Germany) in a materials testing machine (Zwick Roell Z005, Zwick Roell GmbH, Ulm. Germany) by means of a rigid holding rig (Fig. I). The tip of the probe is aligned in the rig so that it moves vertcally downwards into the centre of the specimen holding chamber. This arrangement ensures that all load cell forces are applied vertically and perpendicular to the

\section{MATERIALS AND METHODS}

\section{Ultrasonic device}

A commercially avalable acoustic hon connected to an utrasonic generator was used (Branson Digital Sonfier

meniscal tissue surface, allowing measurement of down ward force by the load cell as the tip of the instrument is placed in contact with the tissue for a range of force and amplitude settings. The load cell is interfaced to computer software and provides a method of direct force

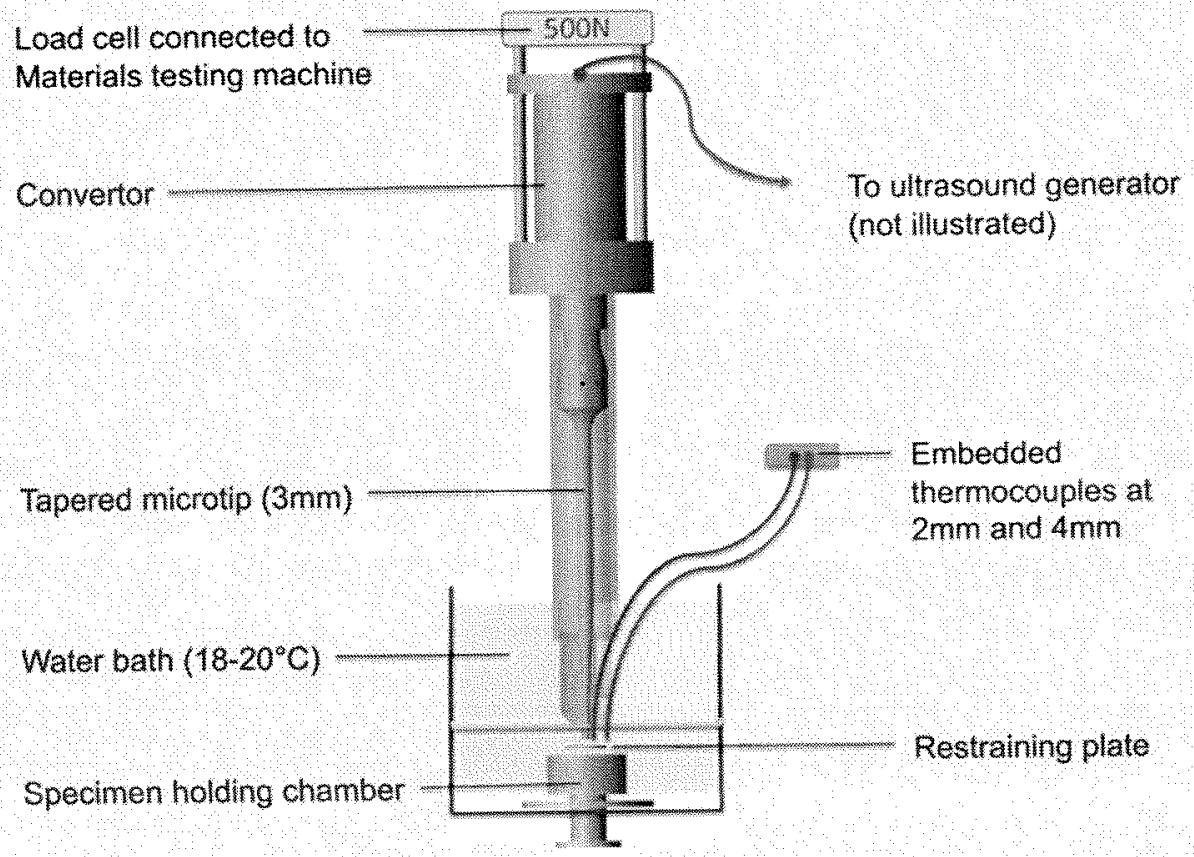

Fig. 1. Experinental rig suspended from $500 \mathrm{~N}$ load oell, 
measurement applied to the tissue samples by the vibrating ultrasonic probe. The arrangement of the load cell ts illustrated in Figure 1 . To examine the effect of variations in force on tissue removal rate, for each exper iment, a specified starting force is selected (range: 2.5 $4.5 \mathrm{~N}$ ). Starting forces were selected based on measured values for clinicians using an experimental ultrasonic chisel for cutting bone (Khambay and Wamsley 2000 ). Crosshead starting position is fixed at $1.5 \mathrm{~mm}$ above the tissue sample and the force is zero-set. Preliminary experiments were conducted in which the ultrasonically vibrating tip was held at a distance of $1 \mathrm{~mm}$ from the surface of the meniscal tissue. For the amplitudes under investigation in this study no damage to tissue was observed grossly or microscopically in these noncontact experiments.

\section{Test soffware}

The crosshead is interfaced to a computer running TestXpert (v 11.2) software (Zwick Roell GmbH, Um, Germany). The initial displacement of the crosshead to find the predetermined starting force (range: $2.5-4.5 \mathrm{~N}$ ) is set at $1 \mathrm{~mm} / \mathrm{s}$. Load and displacement data are recorded every 0.1 s.

\section{Ultrasound}

The ultrasonic generator is started manually for each experiment when the predetermined starting force is reached. The continuous (nonpulsatile) mode is used. The ultrasound generator is switched off when the probe

\section{Meniscal harvesting and storage}

Meniscal samples were harvested from bovine knee joints of freshly slaughtered 12 to 15 -nonth-old steer obtained from a local abattoir. All meniscal samples were used whin $24-48$ h of slaughter. En bloc knees were stored at $4^{\circ} \mathrm{C}$ before experimentation. At the time of experiment, knee joints were disarticulated. Each tibial plateau, with the menisci intact was grossly examined to ensure that there was no damage to the menisei. Menisci were harvested and frozen in $0.15 \mathrm{M}(0.9 \%) \mathrm{NaCl}$ solu tion with protease inhibitors (N-ethylmalemide, 10 mM, benzamide $\mathrm{HCl}, 5 \mathrm{mM}$, ethyldiaminetelracetic acid, $2 \mathrm{mM}$; and $\alpha$-toluenesulphonyl fuoride, $1 \mathrm{mM}$ (Sigma-Aldrich Inc, St Louis, MI, USA) and stored in a freezer at $-20^{\circ} \mathrm{C}$. All specimens were removed from the freezer and allowed to defrost at room temperature for $12 \mathrm{~h}$ prior to testing.

\section{Specimen preparation}

Uniformly circular menscal $(16 \mathrm{~mm}$ specmens were cut from the meniscus using a $16 \mathrm{~mm}$ steel press cuting punch, Specimens were taken from tiskte sections located at the ayascular region of the meniscus (nnex or nedal one-third). Distance from the peripheral rim to the nost peripheral edge of all specimens was consis tently maintained at $25 \%-40 \%$ of meniscal width, to include as little of the vascular zone as possible (Fig. 2) Two surgical blades orientated in parallel $(5 \mathrm{~mm}$ apart) were used to obtain uniformly thick $5 \mathrm{~mm}$ section from circular meniscus samples, Actual sample thickness was measured using a digital micrometer with three measurements taken for each meniscus and a mean thickness calculated Specimens were dried with absorbent paper and weighed in a weigh boat using a balance to obtain initial weight. Specimens were removed and placed in $0.15 \mathrm{M} \mathrm{NaCl}$ solution with protease inhibitors untl testing, to maintain hydration.

\section{Meniscus testing}

A raised specimen-holding chamber $16 \mathrm{~mm}$ diameter $\times 5 \mathrm{~mm}$ ) was placed in a $1500 \mathrm{~mL}$ water bath $(0.15 \mathrm{M} \mathrm{NaCl}$ solution with protease inhibitors) at room temperature. Dimensions of the water bath were 190 $\mathrm{mm}(w) \times 190 \mathrm{~mm}$ (1) $\times 130 \mathrm{~mm}$ (h). Temperature in the water bath was maintained at room temperature $\left(18-20^{\circ} \mathrm{C}\right)$, to simulate arthroscopic conditions. Meniscal specimens were placed in the specimen holding chamber and a restraining plate placed over the holding chamber and screwed into position, submerged in the saline solution bath (Fig. 3). Meniscal tissue was treated in a reproducible manner according to the force and amplitude settings of the experimental group.

\section{Experimental design}

To handle the complexity and difficulty associated with interacting parameters, a response surface methodology (RSM) design was used with both input variables

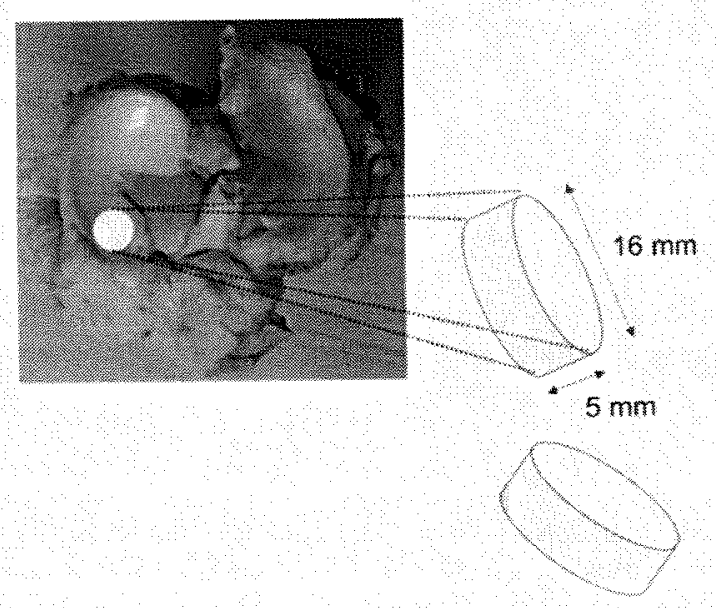

Fig. 2. Meniseal spedmen $(16 \times 5 \mathrm{~mm})$ preparation. 


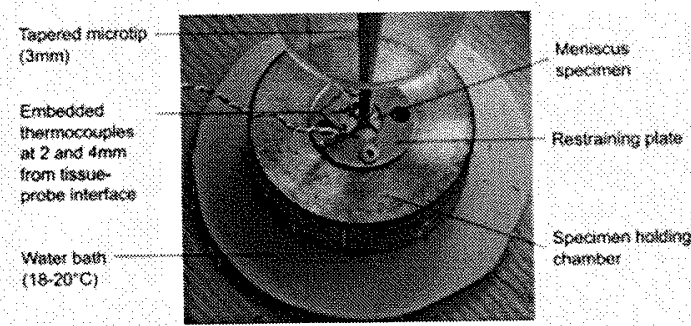

Fi, 3. Meniscal specimens in specimen holding chamber with placemen of thermocouples at distances of $2 \mathrm{~mm}$ and $4 \mathrm{~mm}$ from ultrasonic probe tip. Note cross-hairs to mark centre of meriseal specimen.

$(A=$ amplitude: $B=$ force $)$ treated as continuous (Design-Expert 8.0.3, Stat-Ease Inc, Minneapolis, MN, USA). The individual and interactive effects of these (process parameter) variables were studied by conducting the experiment at randomly selected and different levels of both factors (Table 1). A face-centred central composite design $(\alpha=1)$ was selected to avoid testing-machine constraints at low force settings (Montgomery 1997, Montgomery and Runger 1999). This approach selects a limited number of actual experimental combination or "design points" yet provides a statistically relevant assessment of the experiment (Box and Draper 1971; Myers and Montgomery 2002). This method allows probing into possible experimental interaction between parameters studied and their effect on penetration rate, tissue removal rate and temperature generation.

A 13-trial experiment, with eight unique and five replicate trials was used, each with a specified force and amplitude setting. A total of 52 experiments were performed, with four repeat experiments for each force and amplitude setting and their mean yalue entered in the RSM model.

\section{Inpu and output variables}

Input variables peak-to-peak amplitude of distal tip displacement $(\mu \mathrm{m})$ and force $(\mathrm{N})$ were examined. Tissue

Table 1. Levels of process paraneters ased in the response surface experiment

\begin{tabular}{|c|c|c|c|}
\hline \multirow[b]{2}{*}{ Proces garameter } & \multicolumn{3}{|c|}{ Levels } \\
\hline & -1 & 0 & +1 \\
\hline Applied lonoe $(\mathrm{N})$ & 2,5 & 35 & 4.5 \\
\hline Vhbation anphowade $(p-p)($ amo & 242 & 368 & 494 \\
\hline
\end{tabular}

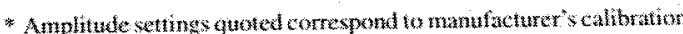

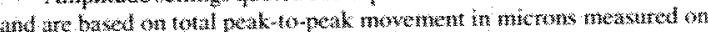

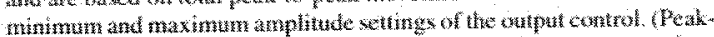

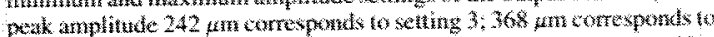

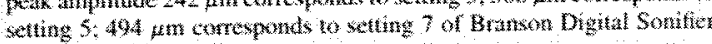
4500 ) removal rate, penetration rate and temperature at spectfied locations were the measured output parameters. The time taken for crosshead fisplacement of $4.5 \mathrm{~mm}$ through the tissue specimen was measured. Once the crosshead has travelled this distance, it is withdrawn away from the specimen and retums to its starting point. At the end of the experiment, the specimen is removed from the specimen holding container. The specimen is carefully dried with absorbent paper. Attention is taken not to remove any debris still atached to the specimen. After drying, the specimen is re-weighed (Chan ef al. 1986. Cimino and Bond 1996). The difference in weight $(\Delta w)$ for each specimen before $(w /)$ and after (w2) ultrasound application is taken as the amount of meniscus renoved by the ultrasonic device:

$$
\Delta w=w_{1}-w_{2}
$$

The tissue removal rate is a time-averaged measurement $(\Delta w / f)$. For each experimental trial, this procedure was repeated 10 times. Similarly, penetration rate $(\mathrm{mm} / \mathrm{s})$ was calculated as the penetration in $\mathrm{mm}$ by the ultrasonic probe, calculated as the difference in position of the crosshead at the start of the experimental trial $(d I)$ and the end of the experimental trial $(d 2)$ :

$$
\Delta d=d_{2}-d_{1}
$$

The penetration tate is a lime-averaged measurement $(\Delta d / t)$.

\section{Temperature measurement}

Thermocouples (type K) (T. M. Electronics, Goring, W Sussex, UK) with negative temperature coefficient and exposed junction were used for temperature measurement as a surrogate marker of protein denaturation and tissue necrosis. Two thermocouples were embedded into the $16 \mathrm{~mm}$ diameter menixeus samples, at distances of $2 \mathrm{~mm}$ and $4 \mathrm{~mm}$ from the probe-tissue interface respectively (Fig. 3). Electrical resistance was measured using analogue to digital meters (Picolog ADC TC-08, Pico Technologies, Cambridgeshire, UK). The neter was interfaced to a computer ruming Pico Log software (R 5.18.0; Pico Technologies). Graphs were plotted for temperature $\left({ }^{\circ} \mathrm{C}\right)$ as a function of time $(s)$

\section{Calculation of temperature elevation}

Temperature elevation was analysed by examinng maximum temperatures generated at each thermocouple, as well as the calculation of daration of time during which the temperature was elevated above $40^{\circ} \mathrm{C}$ for each ultrasound application. This temperature was selected as protein denaturation occurs at a minimum temperature elevation of $4^{\circ} \mathrm{C}$ above body temperature (Amaral 1994). Necrosis in adjacent bone accurs when temperatures of 
45 to $47^{\circ} \mathrm{C}$ are sustamed for periods exceeding 1 min (Goldberg et al. 2005), The area under the curve for which the temperature was greater than $40^{\circ} \mathrm{C}\left(A \cup C_{4}\right)$ was calculated for each graph of temperature $(\mathrm{C})$ as a function of lime $(s)$ by the formula:

$$
A U C_{b 0} 0+=\sum_{i=0}^{n-1}\left(t+1-l_{i}\right)\left(C_{i}+C_{i+1}\right) / 2
$$

Where:

$A U C_{f}, \rho_{l} t=$ Area under a curve $\left(>40^{\circ} \mathrm{C}\right.$ for time 0 to $\left.\mathrm{t}\right)$ $1=$ Time values

$C=$ Temperature $>40^{\circ} \mathrm{C}, \mathrm{o}_{,} \mathrm{C}$, at time $\mathrm{t}$, where $\mathrm{C}$ represents ${ }^{\circ} \mathrm{C}>40$

$n=$ Total number of time temperature points

$l=$ Reference index for $t^{\text {th }}$ temperature-time value.

A graphic representation of calculation of $\mathrm{ALC}_{40}$ is depicted in Figure 4.

\section{Histologic analysis}

For histologic analysis, meniscal specimens were fixed in $10 \%$ formaldehyde in a phosphate buffer $(\mathrm{pH}$ $70 @ 25^{\circ} \mathrm{C}$ histologie fixative, VWR International Ltd., Lutterworth, UK). Samples were dehydrated in

graded series of alcohol and embedded in paraffin. Sixmicron $(6 \mu \mathrm{m})$ sections were cut and stained with hematoxylin and eosin (H\&E). Digital Images were captured using the Aperio ScanScope XT Slide Scanner (Aperio Technologies Ine, Vista, CA, USA). A blinded histologic analysis was performed using image analysis microscopy (ImageScope $v_{*} 10.0$, Aperio Technologies Inc.) by the principal investigator (B.O.D.) with verification of methods by a consultant pathologist with a musculoskeletal interest (C.O.K.). The zone of tissue necrosis and zone of thermal alteration were determined by examining the differential staining of the connective tissue and measuring the maximum lateral themal alteration in tissue adjacent to the cut edges of the meniscal specimen.

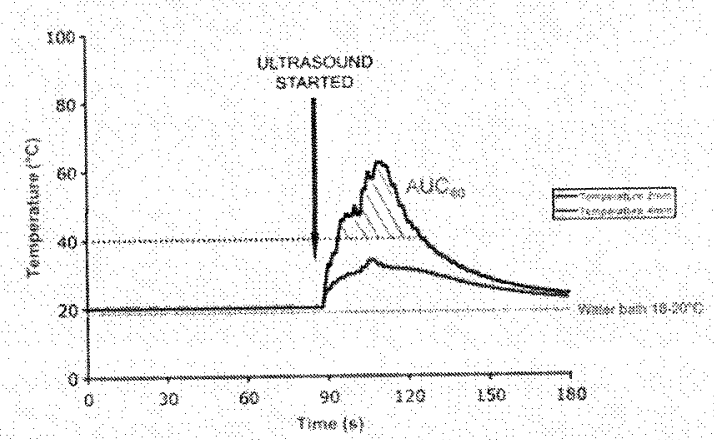

Hg. 4. Graphical representation of eatculation of area under the curve for temperatures greater than $40^{\circ} \mathrm{C}\left(\mathrm{AUC}_{40}\right)$.
The zone of thermal necrosis was defined as that area of meniscus with collagen denaturation, eosinophilic depigmentation and cell necrosis. The zone of thermal atteration was defined as that area of meniscus with abnormal staining patten, as compared with control menisci, with only mild alteration of the extracellular matrix (Sherk et al, 1995, Vangsness et al. 1995 Jazraw ot al. 2003 ). Owing to frequent irregularities in prepared sections and in line with other investigators, a $300 \mu \mathrm{m}$ zone at the surface of the meniscus and also at the tip of the cut were excluded by drawing two parallel lines to the surface of the meniscus (Plotz et al. 1997). The damaged zone between these two lines was measured as the area of tissue necrosis and alteration on both sides of the cut. The average extent of tissue damage was determined as the area on each side divided by the depth of the zone, and a mean value calculated. Histology sections were prepared for one randomly selected speemen, at each of the 13 trial experiment setings as deter mined by the RSM design. To investigate the relationship between temperature elevation and thermal damage, depth of thermal necrosis and alteration for each selected specimen were correlated with $\mathrm{AUC}_{40} 2 \mathrm{~mm}$ and $\mathrm{AUC}_{48}$ 4 mm data for that individual specimen.

\section{Statistical analysis}

Normality was tested using Shapiro-Wilk test. Values for tissue removal rate ( $\mathrm{mg} / \mathrm{s})$ penetration rate (mm/s) and $\mathrm{AUC}_{40}\left({ }^{\circ} \mathrm{C} s\right.$ ) are expressed as mean \pm standard deviation. A two-way independent between groups analysis of variance (ANOVA) was conducted to explore the impact of input variables (amplitude, force) on ottput parameters with post-hoc comparison by Tukey's honestly significant difference (HSD) test. Statistical analysis wat performed using PASW Statistics (v. 18; IBM SPSS Statistics, Chicago, IL, USA). For each response (e.g. tissue removal rate, penetration rate, $\mathrm{AUC}_{40} 2 \mathrm{~mm}$ all possible models from the mean to sixth-order polynomial were calculated using Design Expert sofware. Initial model selection was based on: (1) lack of any aliased terms: (2) low residuals; (3) low $p$ value; (4) significant lack of $f t,(5)$ low standard deviation:(6) high $\mathrm{R}^{2}, \mathrm{R}^{2}$ ad and $R^{2}$,,$(7)$ close agreement between $R^{2}$ as and $\mathrm{R}^{2}$ pred and (8) low prediction error sum of squares (PRESS) value in relation to the other models.

The selected model was then further evaluated according to a battery of adequacy tests (Anderson and Whitcomb 2005). Nomalty was determined by examination of a normal probability plot of the internally studentized residuals and assuring that the residuals fit closely to a straight line. Constant variance was determined by plotting the intemally studentized residuals versu the predicted responses. If the points fell within an interval of +3 standard deviations $(\sigma)$ and exhibited 
a constant range of residuals across the graph, constant variance was assumed. Values for tissue removal rate $(\mathrm{g} / \mathrm{s})$, penetration rate $(\mathrm{mm} / \mathrm{s})$ and $\mathrm{AUC}_{4 \mathrm{p}} 2 \mathrm{~mm}\left({ }^{\circ} \mathrm{Cs}\right)$ are expressed as mean \pm standard deviation.

\section{RESULTS}

Effect of amplitude and force on tissue remowal rate

Large variations in tissue removal rate were observed for different combinations of parameter settings. As amplitude increased (from $242 \mu \mathrm{m}$ to 494 $\mu \mathrm{m})$, there was a linear increase in tissue removal rate (range: $0.92 \pm 0.41$ to $11.16 \pm 4.97 \mathrm{mg} / \mathrm{s}$ ) (Fig. $5 \mathrm{a}$ ). There was a statistically significant main effect for amplitude $[F(2,42)=10.24, p<0.001]$ (partial eta squared $\left.\left(\eta^{2}\right)=.328\right)$ and force $[F(2,42)=10.97, p<0.001]$ $\left(\eta^{2}=343\right)$. Post-hoc comparisons using the Tukey HSD test indicated that the mean TRR for $242 \mu \mathrm{m}$ $(M=1.72, S D=0.89)$ p-p amplitude was significantly different from both $368 \mu \mathrm{m}(M=6.03, S D=3.09)$ and $494 \mu \mathrm{m}(M=7.06, S D=5.48) \mathrm{p}-\mathrm{p}$ amplitude settings. The mean TRR for $2.5 \mathrm{~N}$ force $(M=1.80, S D=1.11)$ was significantly different from both $3.5 \mathrm{~N}(M=5.69$ $S D=3.06)$ and $4.5 \mathrm{~N}(M=8.39, S D=5.52)$ settings. In addition, the mean TRR for $3.5 \mathrm{~N}$ force was signifcantly different from the mean TRR for $4.5 \mathrm{~N}$. The inter-

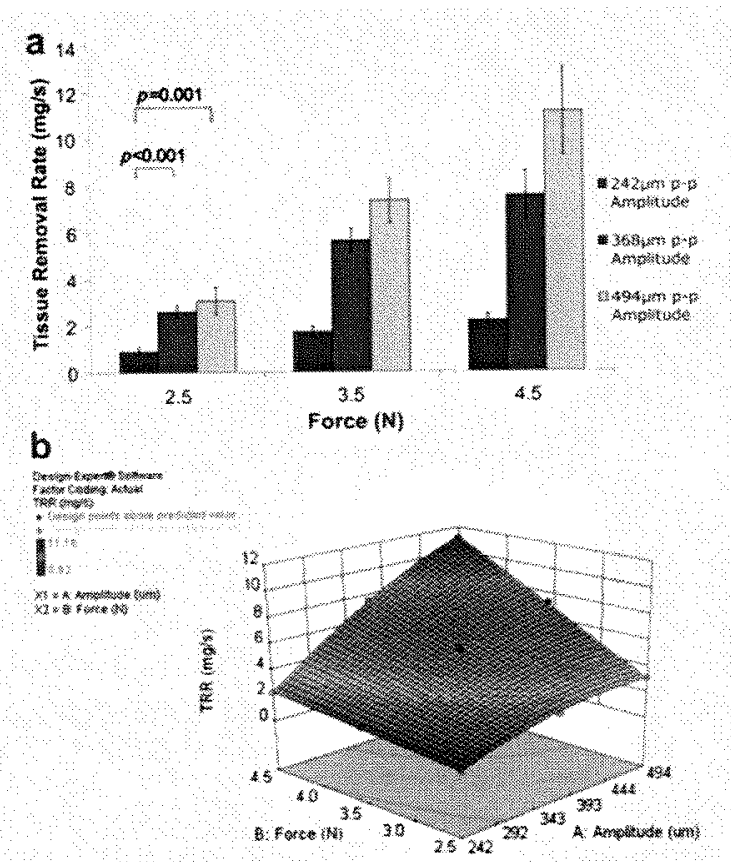

Fig. 5. (a) Effect of variation in force on thisue removal tute (TRR) (nofs) for pop amplitude settings $242-494$ am $(\mathrm{n}=4)$. (b) Response surface methodology (RSM) model for tissuce removal rate (TRR) (my/s) for input parameters $A=$ amplifude; $B=$ force. action effect $\left(F(4,42)=1.74, p=0.161\left(\eta^{2}=.142\right) \mathrm{dud}\right.$ not reach statistical significance. The inter-relationship between issue removal rate, amplitude ind force is shown in Figure 56 .

\section{Effect of amplitude and fore on pentetration rate}

A similar correlation between increases in either force or amplitude and increased penetration rate was observed. As amplitude increased $(242 \mu \mathrm{m}$ to $494 \mu \mathrm{m}$ ), we observed a linear increase in penetration rate (range: $0.08 \pm 0.04$ to $0.73 \pm 0.18 \mathrm{~mm} / \mathrm{s}$ ) (Fig $6 \mathrm{a}$ ). There was a statistically significant main effect for amplitude $[F(2,42)=33.15, p<0.001]\left(\eta^{2}-612\right)$ and force $[F(2,42)=22.60, p<0.001]\left(\eta^{2}=518\right)$. Post hoc comparisons using the Tukey HSD test indicated that the mean PR for $242 \mu \mathrm{m}(M=0.12, S D=0.06) \mathrm{p}-\mathrm{p}$ amplitude was significantly different from both $368 \mu \mathrm{m}(M=$ $0.40, S D=0.12)$ and $494 \mu \mathrm{m}(M=0.51, S D=0.28)$ p-p amplitude settings. The mean $\mathrm{PR}$ for $2.5 \mathrm{~N}$ force $(M=0.16, S D=0.11)$ was significantly different from both $3.5 \mathrm{~N}(M=0.40, S D=0.16)$ and $4.5 \mathrm{~N}(M=$ $0.52, S D=0.27)$ settings. The interaction effect $[F(4,42)=3.23, p=0.21]$ did not reach statistical signifcance. The relationship between penetration rate, ampltude and force is shown in Figure $6 \mathrm{~b}$. From the plot,

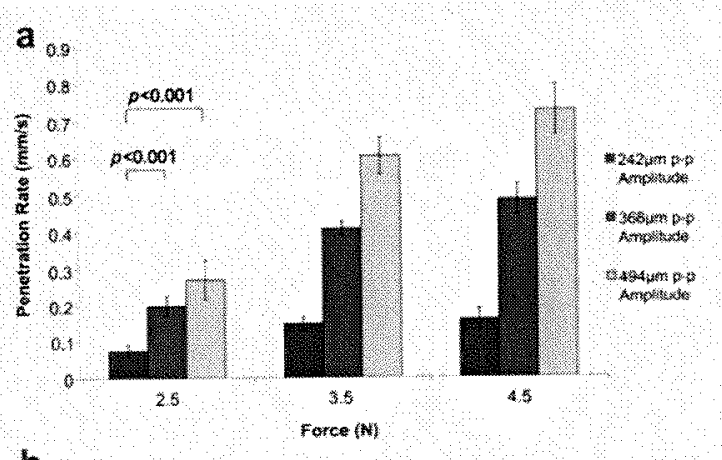

b

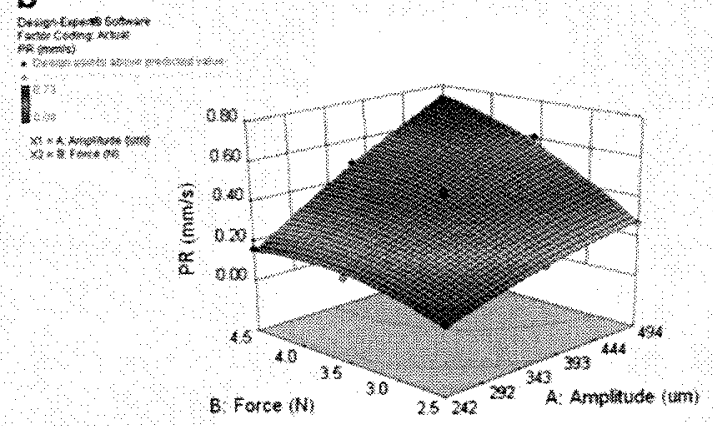

Fig. 6. (a) Effect of variation in force on penetration rate (PR) (nww/s) for po anplitude settings $242-494 \mu m(n=4)$. (b) Responsu surface methodology (RSM) model for penetration fate $(\mathrm{PR})(\mathrm{mm} / \mathrm{s})$ for imput parancter $\mathrm{A}=$ anphitude $\mathrm{B}=$ force. 
a penetration rate for any combination of force and amplitude can be obtained.

\section{Temperature measurement}

Maximum mean temperatures of $84,6 \pm 12.1{ }^{\circ} \mathrm{C}$ and $52.3 \pm 10.9^{\circ} \mathrm{C}$ were recorded in residual tissue at $2 \mathrm{~mm}$ and $4 \mathrm{~mm}$ from the probe-tissue interface, respectively. Minimum mean temperatures of $65.9=11.8^{\circ} \mathrm{C}$ and $39.7 \pm 7.1 \circ \mathrm{C}$ were recorded in residual tissue at $2 \mathrm{~mm}$ and $4 \mathrm{~mm}$, respectively. Temperature readings greater than $40^{\circ} \mathrm{C}$ were recorded for $101 \mathrm{~s}$ for low amplitude $(242 \mu \mathrm{m})$ and low force $(2.5 \mathrm{~N})$ settings. In contrast for high amplitude $(494 \mu \mathrm{m})$ and high force $(4.5 \mathrm{~N})$ settings, temperature readings greater than $40^{\circ} \mathrm{C}$ were recorded only for $13 \mathrm{~s}$.

The highest mean value for $\mathrm{AUC}_{40}$ of $1754.9=$ $1322.11^{\circ} \mathrm{C}$ s was recorded at $2 \mathrm{~mm}$ from the probe-tissue interface for amplitude setting $242 \mu \mathrm{m}$ and force setting of $25 \mathrm{~N}$. The lowest mean value for $\mathrm{AUC}_{40} \mathrm{at} 2 \mathrm{~mm}$ was $272.7 \pm 215.1^{\circ} \mathrm{C}$. recorded for an amplitude setting $494 \mu \mathrm{m}$ and force setting of $4.5 \mathrm{~N}$ (Fig .7a). Similarly, at

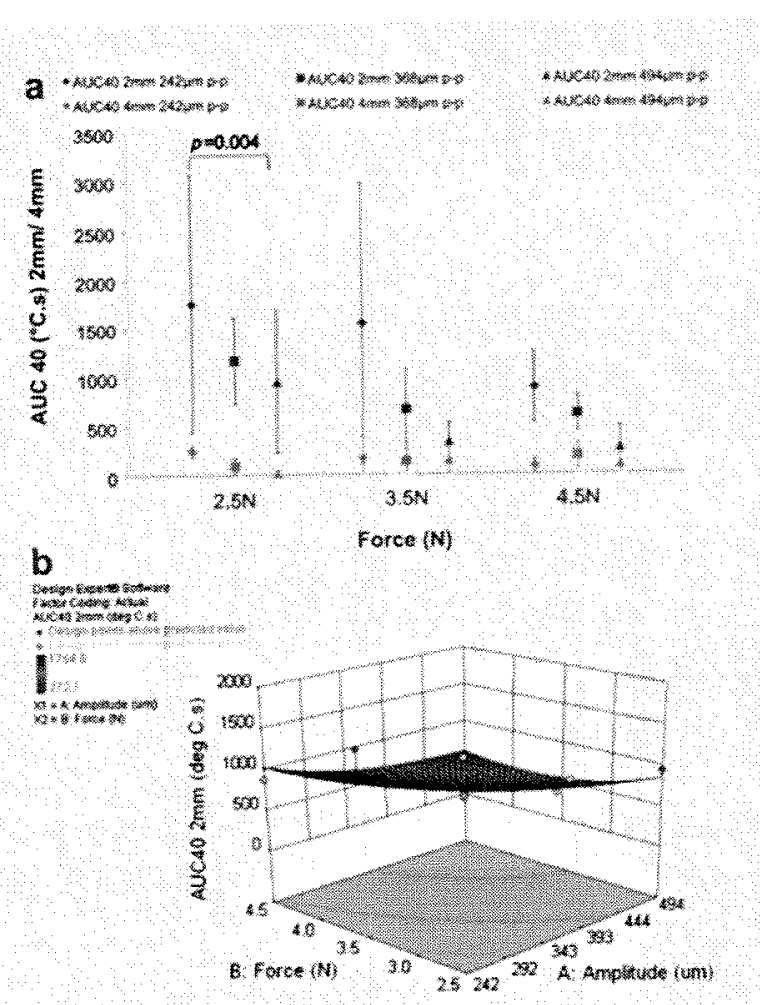

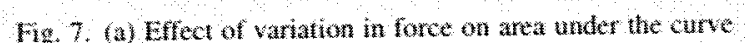
for temperatures greater than $40^{\circ} \mathrm{C}(\mathrm{AUC})\left(\mathrm{C}_{4} \mathrm{Cs}\right)$ at 2 mm (blue) and 4 min (owate) from pobe-tip interface for $p$ -

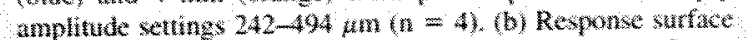
methodology (RSM) motel for area ander the curve at 2 mm

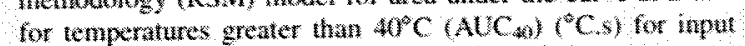
partmeter $A=$ amplitude $B=$ force a distance of 4 mm form the probe-tisste interface, the highest mean value for $A U C$, was $244,6=60.6^{\circ} \mathrm{Cs}$. This value was recorded for low amplitude $(242 \mu \mathrm{m})$ and low force $(2.5 \mathrm{~N})$ setting. The lowest mean value for $\mathrm{AUC}_{40}$ at $4 \mathrm{~mm}$ was $160=27.8^{\circ} \mathrm{C}$ s, recorded for an amplitude setting $494 \mu \mathrm{m}$ and force setting of $4.5 \mathrm{~N}$. For AUC $\mathrm{C}_{40}$ at $2 \mathrm{~mm}$, there was a statistically significant nain effect for amplitude $[F(2,41)=5.71, p=0.006]$ $\left(y^{2}=218\right)$. Post-hoc comparisons indicated that the mean $\mathrm{AUC}_{d 0}$ at $2 \mathrm{~mm}$ for $242 \mu \mathrm{m}(M=1413.04, \mathrm{SD}=$ $1114.93) \mathrm{p}-\mathrm{p}$ amplitude was significantly different from that at $494 \mu \mathrm{m}(M=541.9 . S D=538.9) \mathrm{p}-\mathrm{p}$ amplitude setting. The $368 \mu \mathrm{m}$ p-p amplitude setting did not differ significantly from either of the other p-p amplitude settings $(M=720.6, S D=411.1)$. For $\mathrm{AUC}_{40}$ at $2 \mathrm{~mm}$. the main effect for force $[F(2,41)=1.33, p=0.42\}$ and the interaction effect $[F(4,4)=0.33, p=0.86]$ did not reach statistical significance. We found an inverse relationship between both amplitude and force (Fig. 7b) and temperature elevation, with higher amplitude and force settings resulting in less thermal damage in residual tissue at distances of $2 \mathrm{~mm}$ from the probe-tissue inter-

face For AUC, at 4 mm, we tound no statistical signif icant main effect for amplitude, force or their interaction.

\section{Hotologic analysis}

The maximum depth of zone of thermal nectosis was $184 \mu \mathrm{m}$, recorded tor a $\mathrm{p}$-p amplitude seting of $242 \mu \mathrm{m}$ and a force setting of $3.5 \mathrm{~N}$. The minimum deptt of zone of thermal necrosis was 35 um, recorded for a p-p amplitude setting of $494 \mu \mathrm{m}$ and a force setting of $4.5 \mathrm{~N}$. The maximum depth of zone of themal alteration was $787 \mu m$ again recorded for a $\mathrm{p}-\mathrm{p}$ amplitude setting of $368 \mu \mathrm{m}$ and a force setting of $3.5 \mathrm{~N}$. The minimum depth of zone of themal alteration was $177 \mu \mathrm{m}$, again recorded for a p-p amplitude setting of $494, \mu \mathrm{m}$ and a force setting of $4.5 \mathrm{~N}(\mathrm{Fig} .8)$. As the selection of specimens for evalwation was random and based on the RSM model. the depths of the zones of thermal atteration and neerosis for each individual specimen has been plotted aganst the $\mathrm{AUC}$, recording for that sample (Fig. 8). For the central design point $(3.5 \mathrm{~N}, 368 \mu \mathrm{m})$, where fre repeat trals were performed, the mean depth of zone of thermal alteration was $396 \pm 251 \mu \mathrm{m}$ and the mean cepth of the zone of themal necrosis was $97=44 \mu \mathrm{m}$. Results were not avaliable for one specimen (settings of $2.5 \mathrm{~N}$ force and 494 am p-p amplitude) that was destroyed during histologic preparation. In general, values recorded for p-p amplitudes of 494 fam show a marked decrease recorded in the depth of the zone of themal necrosis and zone of thermal atteration when compared with values recorded for $242 \mu \mathrm{m}$ and $368 \mu \mathrm{m}$ p-pamplitude settings for oquivalen foree settings Histologic images, 


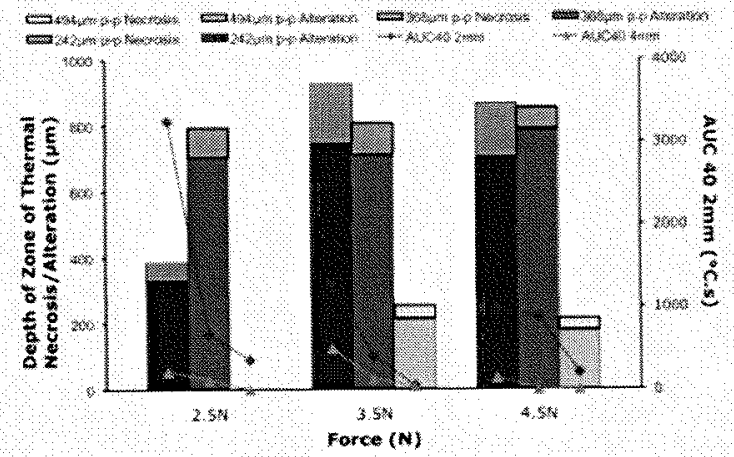

Fig. \&. Effect of wariation in force on depth of zone of thermal necrosis $(\mu \mathrm{m})$ and depth of zone of thermal alteration $(\mu \mathrm{m})$ for p-p amplitude settings $242-494 \mu \mathrm{m}$ (bar chant) and comparison with area under the curve for temperatures greater than $40^{\circ} \mathrm{C}$ (AUC $\left.{ }^{\circ}\right)(\mathrm{Cs}$ ) at $2 \mathrm{~mm}$ (blue line traph) and $4 \mathrm{~mm}$ (orange line graph) from probe-tip interface for corresponding specimens at p-p amplitude settings $242-494 \mathrm{~mm}(\mathrm{n}=1)$. Note specimen for $2.5 \mathrm{~N}$ force and $494 \mu \mathrm{m}$ p-p amplitude destroyed during histologic preparation,

illustrating the zone of thermal alteration and zone of thermal necrosis are shown in Figure 9.

\section{RSM analysis}

Results for experimental and simulated values are listed in Table 2. Outpat parameters in each experimental run were analyzed using the software and fitted into a multiple nonlinear regression model. The coefficient of the model for the response was estimated using multiple regression analysis techique included in the

RSM. The response was newsured in terms of tisse removal rate, penetration rate and temperature generation. The guadratic models obtained were given as follows:

$$
Y_{r k k}=521+279 x_{1}+238 x_{2}+170 x_{1} x_{2}-0.81 X_{1}^{2}
$$

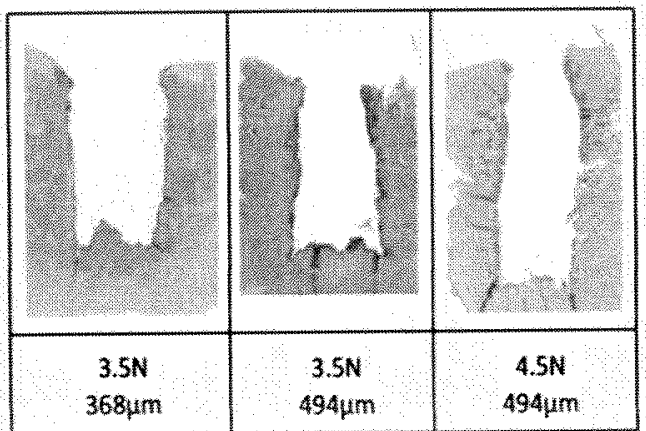

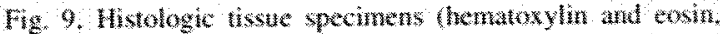
Hote $\times 5$ power Illustrating zone of thermal mecrosis and zone of htermal alteration.
$X_{1}=$ mplitude and $X_{2}=$ force and $Y_{T K}-$ hssue renoval rate

$$
\begin{aligned}
& x_{*}+0.41+0.2 x_{1}+0.14 x_{2}+0.094 X_{1} x_{2}-0.029 x_{1}^{2} \\
& -0.067 x_{2}^{2}
\end{aligned}
$$

$Y_{p k}=$ penctration rate

$$
\begin{aligned}
& Y_{A x_{2}}=724.87-436.95 X_{1}-350.37 X_{2}+45.58 X_{1} X_{2} \\
& +161.81 x^{2}+111.36 x_{2}^{2} \\
& Y_{N / 2 \text { mm }}=\text { area under curve }\left(40^{\circ} \mathrm{C}\right) \text { ar } 2 \mathrm{~mm}
\end{aligned}
$$

Accuracy of the mode?

Analysis of variance (ANOVA) of regression is summanzed in Table 3. The maximum predicted responses for optimum setings of applied force and vibution amplitude was obtained through point prediction method and surface response plots. The optimum values of $4.49 \mathrm{~N}$ applied force and $493 \mu \mathrm{m}$ vibration amplitude were determined. These values predict a meniscal TRR of $11.17 \mathrm{mg} / \mathrm{s}$, a PR of $0.74 \mathrm{~mm} / \mathrm{s}, A U C_{\text {a }}$ at 2 mm of $257.3^{\circ} \mathrm{C}$, . The correlation coefficient $\left(R^{2}\right)$ values for the model are high (Table 3). The precision for the chosen model indicates that the signal-to-noise ratio of the data is adequate for these analyses. The coefficient of variation $(\mathrm{CV})$ for this response is low, indicating very close agreement between duplicated measurements in the nodel.

\section{DISCUSSION}

The purpose of this study was a quantitative in wito evaluation of ultrasound effeacy and tissue effect. The intention was to measure tissue removal rate, penetration nate, thermal and damage data on an whasound system operating in a controlled setting. In this study, we have shown that for meniscal tissue, responses in tixsue removal rate, penetration rate and temperature elevation can be predicted for a force controlled ultrasonic probe on the basis of atterations in user amplitude and force settings. Increases in amplitude and fore setting resulted in increased tiskue removal rate, increased penetrition rate and reduced temperature elevation in adjacent residual meniscal tisket. In addition, this study provides confirmatory evidence of ussue necrosis and tissue alteration occurring at a cellular level in response to temperat ture elevation. We found hat higher amplitude and higher force settings are associated with better performance (inereased TRK: increased PR) and reduced temperature elevation and reduced tissue damage. Our findings suggest that an ultrasonic instrument that exploits these operating characterstics may have potential in joint 


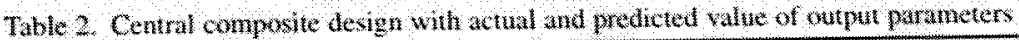

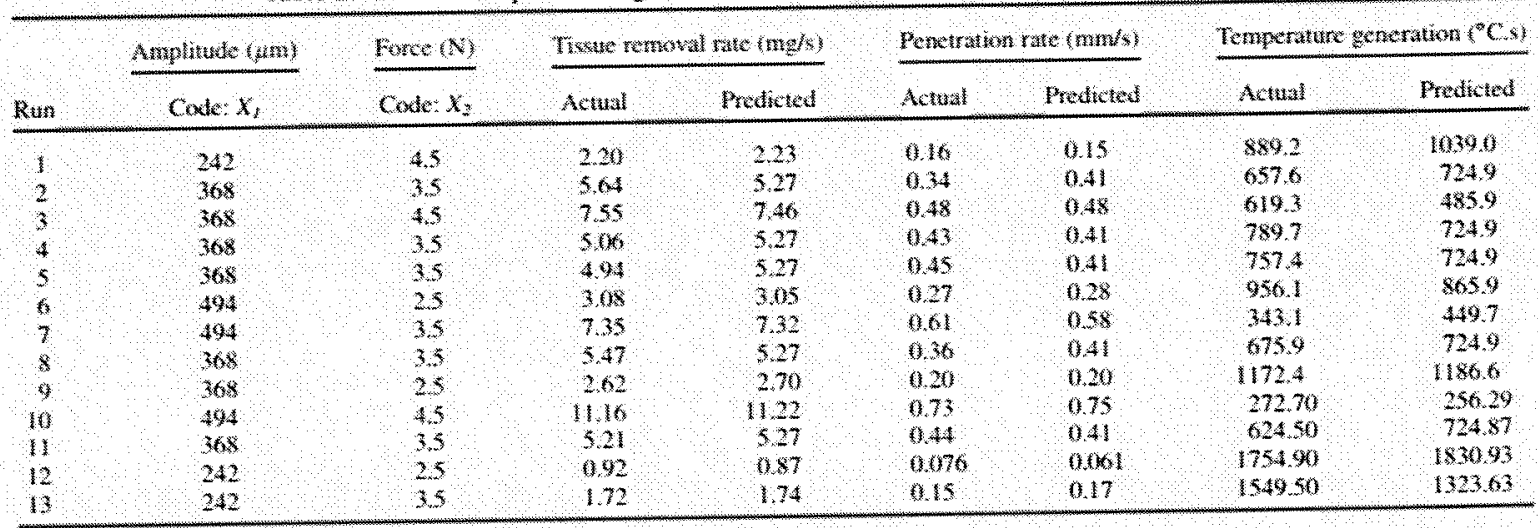

arthroseopy for meniscal and other hard fbrous tissue debridement in yivo

This study employs a llat probe tip design without modification; eliminating artefacts of geometry that might be assoctated with commercially available probe tips for ultrasonic devices. We did not seek to address how different probe tip geometries might affect performance of an ultrasonic device with these operating parameters. There is no accepted objective means of measurement permitting comparison between individual ultrasonic device control parameters (Cimino 2001). This hinders comparison between individual designs and systems as a basis for interpreting clinical outcomes. With this in virro model, using fresh-frozen meniscal tissue, we attempted to represent the acute mechanical and thernal change that would be seen had the study been performed in wivo. The implications of the thermal and histologic changes observed and more specifically.

Table 3 Analysis of wariance of the calculated response surface methodology (RSM) mode:

\begin{tabular}{|c|c|c|c|}
\hline & 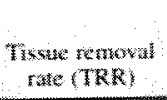 & $\begin{array}{l}\text { Persetration } \\
\text { rate (PR) }\end{array}$ & 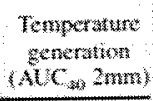 \\
\hline \multicolumn{4}{|l|}{ terressons } \\
\hline Swm of syatre & 56 & 0,2 & $2004 \times 10^{6}$ \\
\hline dF & 5 & 5 & \\
\hline Mean scturats & 1891 & $0,0 \%$ & $\$ 19 \times 10^{*}$ \\
\hline F value & 371.98 & 50,56 & 26 \\
\hline p vat & cosol & comol & nows \\
\hline Aeridual & & & 1 and $\times w^{3}$ \\
\hline 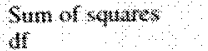 & 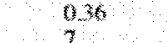 & 0012 & $\frac{1363 \times 16}{7}$ \\
\hline Af & bost & $1668 \times 10^{-3}$ & $19 \% 604 \%$ \\
\hline 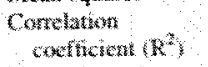 & 09662 & 0073 & $0936 \%$ \\
\hline $\begin{array}{l}\text { Cocfichent of } \\
\text { vartation (CVk) }\end{array}$ & 466 & $1 / 31$ & 1658 \\
\hline
\end{tabular}

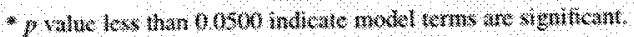

how they might relate to load transmission across the knee is not known.

This study uniquely provides thermal damage data for a fibrous tissue subjected to a high-frequency lowenergy ultrasound device. We observed a maximum depth of zone of thermal necrosis of $184 \mu \mathrm{m}$ and a maximum depth zone of themal alteration of $787 \mu \mathrm{m}$ in adjacent residual tissue. Our figures are comparable with reported tisste damage figures for electromagnetic and laser meniscus laboratory surgery. In studies evaluating laser and electrosurgical devices, injury to cartilage and meniscal tissue has been reported, ranging from almost undetectable to $1980 \mu \mathrm{m}$ in depth (Polousky et al. 2000 , Vangsness et al. 2002; King tet al. 2005). Additionally. large variations have been reported within experimental groups (Vangsness ef al 2002). The large range of variafion in thermat damage among studies may be explained by differences in experimental protocol and by defintrons

of what consintutes thermal damage $A$ laboratory study examining the biologic effects of water-bome $25 \mathrm{kHz}$ ultrasound on murine lesticular tissue demonstrated complete absence of themal damage, instead impicating microstreaming as the physical mechanism of ultrasoundtissue interaction (Carnes and Dom 1986). Murne testic ulat tissue is known to have high water content and a low ultrasound aborption coefficten value. In their study, duration of titrasound exposure, and distance of the ultrasound device from the tissue specimen determined the extent of hastologic damage effects. The authors ruled out themal cffects as the source of tissue damage by calculating that temperature elevation in excess of $10 \mathrm{C}$ in testes vissue was not possible using their experinental $15 \mathrm{~W} / \mathrm{en}^{2} \mathrm{intensity}^{2}$ ultrasound device. In comparison, we found that the higher spatial-averige-temponal-average intensity values of $312-1298$ W/em reguired for whasonic abtation of hatd hbrous mentseal tissue result in themal damaxe. In a histologic study of fracture healing 
using low-intensity pulsed ultrasound in bone, Duarte demonstrated a negligible thernal effect, with temperature elevation of less thin $0.1^{\circ} \mathrm{C}$ (Datate 1983). Restits in this study found that utrassonic energy, with appro priate parameters, can accelerate fracture healing. It is concluded that a nonthermal origin piezoelectric effoct is responsible for the stimulation mechanism in hard tissues such as bone. Results in both of these studies are in contrast to our study, which implicates thermal damage as a principal tissue damage mechanism in fibrous menis cal tissute.

Results in this study can be compared with tissue ablation rates reported for visceral tisste (Chan et al 1986. Cimmo and Bond 1996). In common. we found that p-p amplitude of distal tip vibration is an important determinant of tissue renoval rate. Rates of removal reponted for visceral tisste range from $0 \mathrm{mg} / \mathrm{s}$ for aorta. $25 \mathrm{mg} / \mathrm{s}$ for liver tissue, to $484 \mathrm{mg} / \mathrm{s}$ for brain tissue (Cimino and Bond 1996) In another study using a different device, Chan reported a removal rate of 131 $\mathrm{mg} / \mathrm{s}$ for liver tissue (Chan ot al 1986), Our maximum rate of $11 \mathrm{mg} / \mathrm{s}$ falls within the range reported. Neither of the studies on visceral tissue address thermal or other damage in adjacent residual tissue. In comparison to the current study, neither study attempted to control for applied user force. However, our results demonstrate that alteration in user force significantly affects rate of tissue removal.

There are a number of limitations to our study design. This experiment aimed to standardise meniscal ablation by using an experimental set-up employing a range of forces $(2.5-4.5 \mathrm{~N})$ that might be applied manually in aclinical setting. A similar force-controlled experimental set-up has been used by Vangness ef al. to study meniscal

ablation by radofrequency ablation (Vangsness et al 2002). Although it is clear that chinical arthroscopic use involves moving an instrument over the surfice of a meniscus, this sudy employs an thrasonic probe held in contact with meniseal tissue at a single point for the entire duration of the experiment, potentially exaggerating damage effects in residual tissue. It is highy unlikely that any arthroscopic technique would require holding the instrument in a single posinion for a prolonged period of time and actual damage in tissue may be less. Studies of bote catting have shown that if a high temperature is mantained only for very shon periods, temperatures in excess of the commonly cited temperature of themal necrosis will not result in necrosis (Malawer et al 1999 Lucas ot al. 2005). Notwithstanding. we believe that ou force controlled experinental design allows maximum control over input parameters and yictds useful data that may be applied elinically in instrument design.

We observed large variations in values recorded tor $\mathrm{AUC}_{\text {ax }}$ data, with low testretest reliability between four dentical experimental setings at each of 13 tral expernent setings. Variations in time taken for the ultrasound probe to penetrate the tissue sample are primarily responsible for this difference. The observed variation may result from the heterogenteous composition of and anisotropic response to loading in meniscal tissue samples (Fithan et al. 1990), Others have also reported large variations in thermal damage for meniscal tisste within experimental groups (Miller et $\mathrm{al}$ 1987, Vangsness of al, 2002), The use of $\mathrm{AUC}_{\text {w }}$ values as a surrogate marker for tissue necrosis and alteration is further questioned by the findings of large differences in values for depth of zone of thermal neerosis and depth of zone of thernal atteration among individual specimens. As only one specimen was tested at each of 13 trial setings, rather than all four and a mean obtained findings in the current experiment clearly need to be interpreted with cation. Although a general trend toward a reduction in thermal damage at a cellular level is seen with increases in both force and amplitude, it is not apparen why this is not true at the lowest input setting for both parameters, in this experiment $242 \mu \mathrm{m}$; $2.5 \mathrm{~N}$ ). Further work is required to determine what modes of tissue-ultrasound interaction are occurring at each input paratneter setting and whether cavitation is occurring at low amplitude setings for this device (Wells 1984).

The results in this study suggest that by judicious control of amplitude and load it is possible to design an ultrasonic cutting device for meniseal and fibrous tissue debridement that minimizes tissue damage during cutting This technology warrants further investigation and refinement, to demonstrate equivalence or superiority to cument menical resection methods.

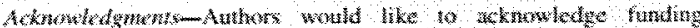

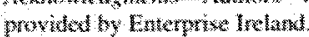

\section{REFERENCES}

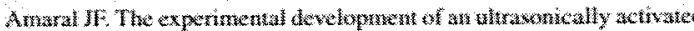

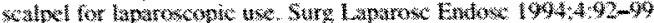

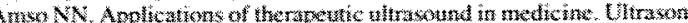

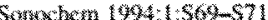

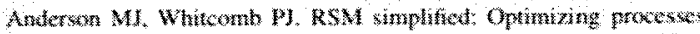

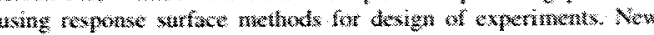

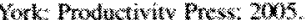

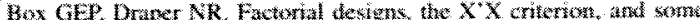

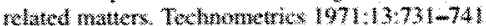

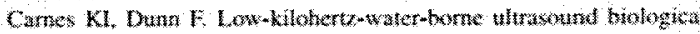

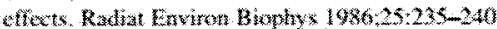

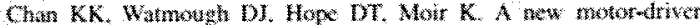

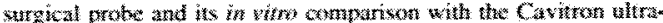

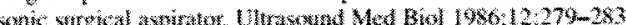

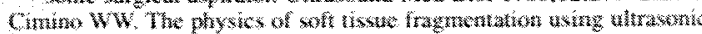

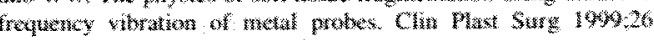
$47-46$

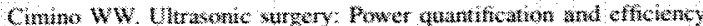

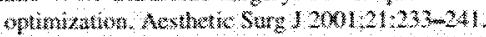




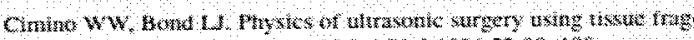

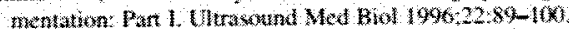

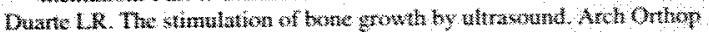

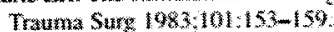

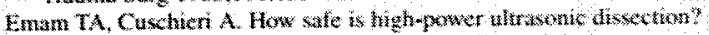
Axw Surs 2003;237:186-191

Fothian DC, Kelly MA Mow VC. Moterial properties atul stractare*

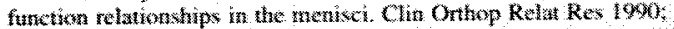
$252 * 1 \times-31$

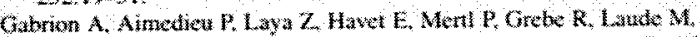

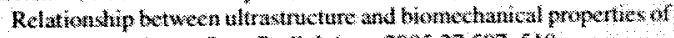

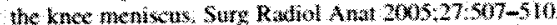

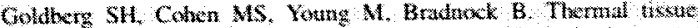

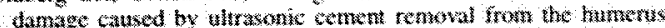
1 Bone Jöru Surg Am 2005,87,583-591.

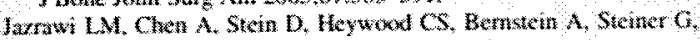

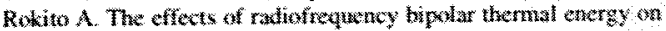

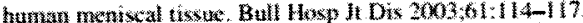

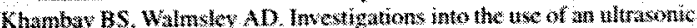

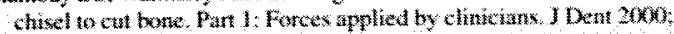
$28,31-37$.

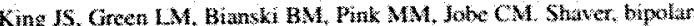

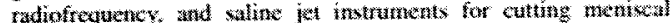

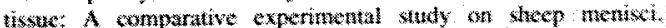
Arthroscopy $200521: 844-850$

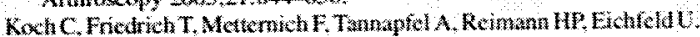

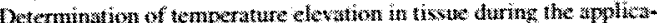

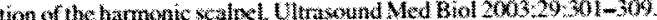

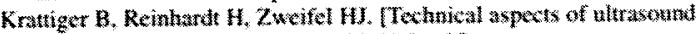

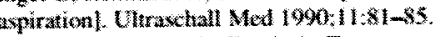

Lueas M. Cartoni A, MacBeath A. Temperature effeces in witricons cuting of natural materiats. CIRP Annats $300,54.55-1 \%$

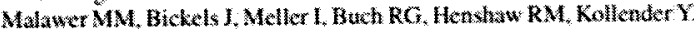

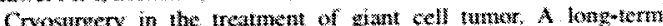
follow-up wudy. Cin Orh Rel Ras 1999,359:176-18x.

Miller GK, Drennu DB. Maglahn DI. The effect of techniquse on histology of arthroscopic partial menisectomy witle chetrowurgery Arthroseopy $1987,3: 36-4$.

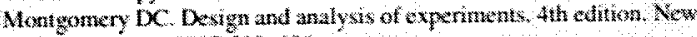
York: Wiley: $1997,599-60 \%$

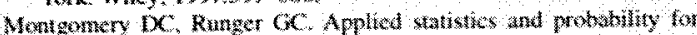

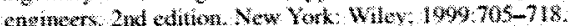

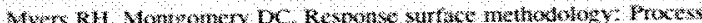

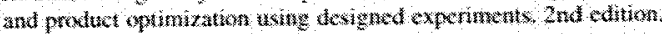
New York Whey: 2012 .

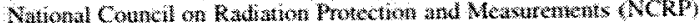

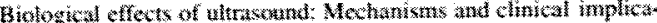

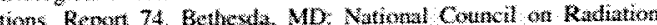
Protecton and Measurement 1983

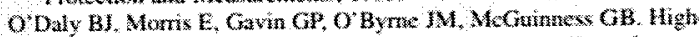

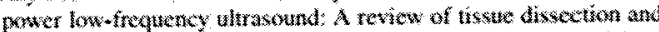

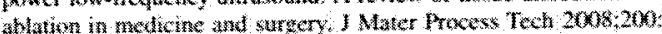
$38-5$.

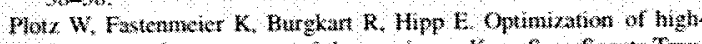

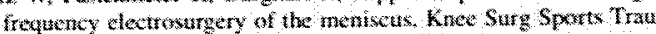
matol Athoxe 19975 184 18.

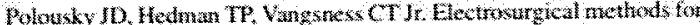

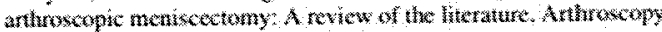
$2000,16: 813-321$

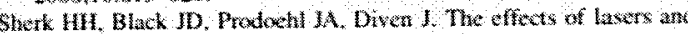

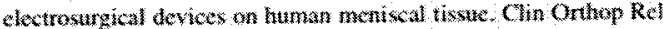
$\operatorname{Res} 1995,310: 4-20$

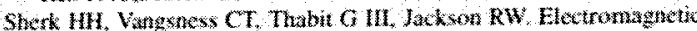

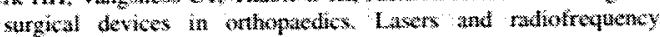

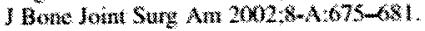

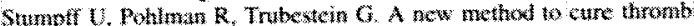

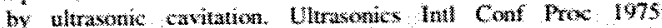
$27 \times-275$

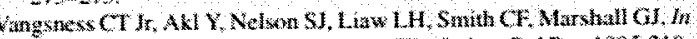

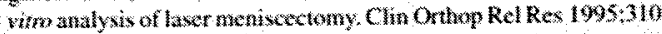
$21-20$

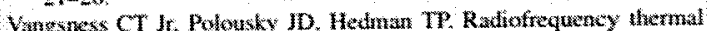

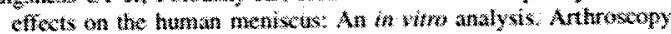
$2002,18,492-405$

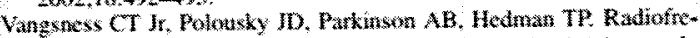
atency themal effect on the human netikets. An in vitro sudy

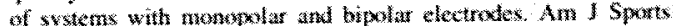
Mod $200 \%, 31.253-256$.

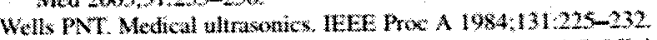

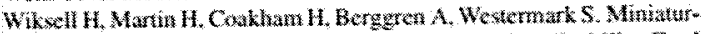

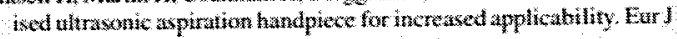
Itraswand $2000: 11: 41-46$

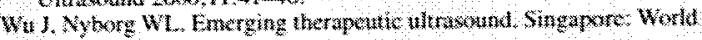

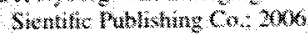

